\title{
Creating connections for expansive learning in crisis-laden times of long-term unemployment
}

\section{Franziska Bonna}

University of Bremen, Institute Technology and Education (ITB), Germany (bonna@uni-bremen.de)

\begin{abstract}
This paper deals with the crises of long-term unemployment using subject theory, biographical research and critical theory as the framework. Based on narrativebiographical interviews with long-term unemployed people, I identify the factors and conditions that turn long-term unemployment into a crisis, arguing that expansive learning processes and the competence of utopian thinking are essential for creating visions of one's occupational future as well as (social) utopias, thus, being a way out of these crises. The findings of the data show that subjective crises in times of prolonged unemployment are not always caused by unemployment itself and that existing visions of the occupational future cannot always be pursued.
\end{abstract}

Keywords: Critical-reflexive adult education, expansive learning, long-term unemployment, social competences, utopian thinking

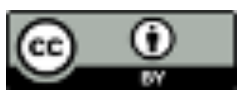




\section{Introduction}

After years of what has been termed the 'economic miracle' and low rates of unemployment in Germany, mass unemployment was dominant in the 1980s and 1990s. ${ }^{1}$ At the time, the research in German adult education on unemployment was broad. Besides psychological and sociological research on the consequences of unemployment, adult education focused on the self-perception of unemployed people (Peters, 1991), on the intended and unintended benefits of further education for this group (Meier, 1998) and on educational concepts (Epping et al., 2001). The last high point in German unemployment statistics was reached 2005. This was also the year when the fourth and final step of the German labour market policy reforms ('Hartz reforms') was implemented. Since these Hartz reforms, unemployed people have been divided into two groups and have been relegated to two different legal systems: Sozialgesetzbuch II ('Social Legislation Act II') and Sozialgesetzbuch III ('Social Legislation Act III') — SGB II and SGB III - each with different monetary benefits and educational interventions. The new labour market policy is conducted based on the slogan and practice of 'promoting and demanding' (Fördern und Fordern), aiming to reintegrate unemployed people as quickly as possible to reduce the unemployment rate.

Since these structural changes to German labour market policy, the number of unemployed people has continuously declined (before the COVID-19 pandemic). Comparing current rates of unemployment with other European countries, Germany remains along with the Netherlands and Czech Republic as being one of the countries with the lowest rates of unemployment, whereas Greece and Spain have the highest rates by far (cf. Eurostat, 2021). However, in Germany, the number of long-term unemployed has stagnated for years (Bundesagentur für Arbeit, Statistik/Arbeitsmarktberichterstattung, 2019, p. 6). This means that the proportion of long-term unemployed people has been increasing. Even though the structural problem of mass unemployment in Germany has decreased, long-term unemployment is still a problem and is linked to discrimination, stigmatisation and exclusion (Butterwegge, 2015; Kronauer, 2007). Not only the long-term unemployed are affected by the Hartz reforms, but also further education, because, among other things, courses funded by the employment agency must be certified according to certain criteria. Therefore, unemployment under the conditions of the Hartz reforms is again receiving more attention in adult education research (Bonna, 2018; Hermeling, 2017; Teiwes-Kügler, 2017).

From a subject science theoretical, biographical and critical perspective, this contribution aims to discuss the link between the individual and social crisis of long-term unemployment, German labour market policy and learning processes. This is done with reference to a completed dissertation project in which the following questions were examined using a qualitative biographical research approach: 'What ideas do long-term unemployed people have of their occupational future?' 'How are these visions embedded in the political and societal conditions and in awareness of their own competences, experiences and biographical learning processes?' The main result is three types of visions of long-term unemployed people's occupational future. The dissertation and an article focusing on and presenting these future vision types have already been published (Bonna, 2018; 2017). In the current article, the focus is on the factors and conditions that turn long-term unemployment into a perceived crisis by those affected and on the way the experience of unemployment as a crisis affects the development and pursuit of ideas of the occupational future, including the related learning processes. 
By way of introduction, I first discuss the significance of work and unemployment in a modern labour society and present the reformed German labour market policy. This is important for understanding the German context of the political and societal conditions of the empirical study under scrutiny and for the interpretation and analysis of the subjective and biographical viewpoint of long-term unemployed people. Second, I introduce the terms, utopia/utopian thinking and learning. I define these terms by referring to critical theory, the concept of social competences by Oskar Negt (2010) and the subject theory of learning by Klaus Holzkamp (1995). In a third step, I present the final results of my biographical research, which include three types of visions of the occupational future and a view of the crisis-laden conditions of long-term unemployment. The contribution ends with the conclusions for learning in the crisis of long-term unemployment.

\section{The significance of work in a capitalist society in times of 'erosion crises'}

In a capitalist industrialised labour society, work is primarily understood as gainful employment. Work serves to secure one's livelihood and finance leisure and consumption, which, in turn, is intended to secure the relations of production. Besides its economic function, work also has a psychosocial function. It enables social contacts, serves to structure time and space and conveys the feeling of social recognition and of being needed. Although voluntary work and care work have gained more attention and recognition and research also shows the meaningful, identity-creating and competencebuilding function that these forms of work have for the individual and society (Benedetti, 2015; Dehnbostel, 2007; Düx et al., 2009; Semmer \& Meier, 2014), these forms of work still does not generate the social recognition that paid work does. Since the 1980s/1990s, the processes of individualisation, flexibilisation, the dissolution of boundaries between work, family and leisure on a spatial and temporal level, the decline of jobs and professions, the increase in atypical, precarious and discontinuous employment relationships and the increased risk of unemployment (in all social classes) have marked a crisis within the working society. The social philosopher Oskar Negt describes these changed working conditions (and the increasing mass unemployment of the 1980s and 1990 s) that affect society as a whole as one of five current erosion crises of the capitalist society (Negt, 2010; Rasmussen, 2021). Erosion crises differ from general crises because of their impact on the individuals' physical, psychological and mental resources (Negt, 2002, p. 123). Negt compares erosion with Emil Durkheim's term 'anomy', which is characterised by the loss of familiar norms and disorientation, while new orientations for action are still missing. Erosion crises cause the critical conditions of isolation, fear, powerlessness and helplessness (Negt, 2002, p. 123). They affect many individuals and, hence, are collective crises, too. Negt's critique of the capitalist society of gainful employment and the associated superficial economic function of work is primarily directed at alienated work processes characterised by the exploitation, oppression and degradation of the human being into a workforce. Nevertheless, he also recognises in this concept work as 'a medium of self-liberation' (Negt, 2012, p. 3; translated by the author); he argues for a broadening of the concept of work, in which also other forms of work find social recognition, which he understands as 'living work' (lebendige Arbeit) (Negt, 1984; Salling Olesen, 2013). Living work serves self-production and self-realisation, promoting the perception of 'Mündigkeit' (empowerment) and helping in identity building. These are conditions with which future perspectives and motivation to participate in shaping the future and society can be developed (Negt, 2002, p. 429). 


\section{Long-term unemployment in times of changed labour market policy}

One of the oldest and most well-known studies on long-term unemployed people in German-speaking countries is the Marienthal-Studie ('Marienthal study') from the early 1930s (Jahoda et al., 1986). Due to the unexpected shutdown of the local plant from one day to the other, the whole Austrian village of Marienthal was suddenly affected by unemployment. A research network visited, observed and interviewed the people living there. In order to gain a broad and deep insight into the impacts of the social rupture, multifaceted quantitative and qualitative methods were combined in that research, marking a milestone in social science studies. One of the main results of the Marienthal study is the identification of four types of attitudes towards the crisis of full unemployment: the unbroken, the resigned, the desperate and the apathetic (Jahoda et al., 1986, p. 73). The difference with today's situation is that phases of unemployment can affect all social classes, but mass unemployment is currently no longer a problem. However, long-term unemployment can be seen as a central problem in today's world because the number has stagnated in the last 15 years compared with the decreasing number of unemployed people in general. In addition to changes in the work society, Negt (2002) describes high unemployment as a central symptom of social erosion crises.

In Germany, people are considered long-term unemployed if they have been unemployed for a year or more. Around 90 percent of the long-term unemployed are assigned to the legal category SGB II; they receive basic income support to ensure their livelihood. In addition, basic benefits are given and include counselling services to reduce and end the need for assistance through integration into training or work. The promotion of continuing vocational training is not included in SGB II. Since the Hartz reforms, this has been regulated through the allocation of education vouchers in SGB III. Consequently, only unemployed persons who are assigned to SGB III, which does usually not include the long-term unemployed, are entitled to education vouchers, though education vouchers may also be awarded to the long-term unemployed in SGB II at the discretion of the employment agency.

The allocation of such vouchers is supposed to take place in a joint discussion between the unemployed person and the placement officer, in which the educational goal and duration of the envisaged continuing education are jointly determined. However, studies on these allocation processes show that the educational goal is often determined by the placement officer alone and that the unemployed have hardly any opportunities for codetermination (e.g., Ludwig-Mayerhofer et al., 2009). After receiving an education voucher, the unemployed person receiving benefits must independently search for a suitable continuing education offer. This is done via a digital course portal without further counselling support; therefore, it requires at least basic digital and literacy skills. It can be difficult to navigate a large number of continuing education providers and courses, especially for people who have never participated in continuing education before. In addition, the education voucher may only be redeemed for a continuing education activity that is certified and recognised by the Federal Employment Agency. This is a very obvious example of the concept of providing help (promoting), but also demanding that people take a large amount of responsibility for their future.

With the aim of rapid reintegration into gainful employment, since the Hartz reforms, the unemployed have been obliged to accept any job within so-called reasonable limits (Zumutbarkeitsregelung). This means that neither the once learned profession nor the qualifications of the respective unemployed person have to be necessarily taken into account when placing them in work. These regulations according to the parameters of reasonability very often force the unemployed to change their wishes, career plans and 
life concepts - or even to lose sight of them altogether (Ludwig-Mayerhofer et al., 2008, p. 285ff.).

The new Hartz policy and the allocation of education vouchers have been strongly criticised in adult education because support (promoting) opportunities are unequally distributed and the demands require personal responsibility, flexibility and employability of the recipients of labour market policy benefits (e.g., Brödel, 2018; Reutter, 2009; Teiwes-Kügler, 2017). Subjectivity and self-determination are often not considered.

Against the backdrop of the capitalist understanding of work, the erosion of the work society and the incapacitating conditions of labour market policy, it is questionable not only whether and how the long-term unemployed develop, maintain and actively pursue visions of their occupational future, but also, how these conditions turn long-term unemployment into a crisis.

\section{Utopias and utopian thinking as a space of possibilities to overcome crises}

Questions directed at the visions of the occupational future of long-term unemployed people and at the conditions leading long-term unemployment to a subjectively perceived, but also collectively experienced crisis can be answered with a view to concepts of utopia. In this article, I present a philosophical-social understanding of utopia based in critical theory. Utopias, according to this, are visions that often arise in times of societal crises or societal transitions (Faulstich, 1990, p. 16). They consist of both a criticism of present social conditions and the wish for a better life and better life conditions in the future (Negt, 2002); consequently, they are alternative drafts of the existing social conditions. Utopias allow people to think about possibilities in the future and create hope for a life full of happiness and equity (Horkheimer, 1986, p. 189). Max Horkheimer defines utopias as 'a dream of a real and equitable order of life' (Horkheimer, 1930, p. 6; translated by the author). Thinking about the future is important because it allows us to escape from (crisis-laden) reality and to open up ideas of what might be possible. The aim of utopian thinking is to create an everyday consciousness of social structures and the possibilities they contain for the subject (Negt, 1984, p. 205). Thus, utopian thinking is a possibility for individual wishes and hopes, as well as for collective visions to create a better life and better society.

However, utopian thinking requires a specific competence that must be learned. In parallel with and in criticism of the neoliberal-grounded debate on qualification, key qualification and competence, Negt has developed the concept of 'social competences' $(1993,2010)$. Social competences aim at an awareness of connections between individual interests and objective conditions and at critical political education (Negt, 2010; Rasmussen, 2021, p. 23; Zeuner, 2013). 'Creating connections' is understood by Negt as a meta-competence and as a learning process that is not about the acquisition of knowledge but about the development of a sociological way of thinking that allows an action-empowering process in the midst of a world with rapidly changing information (Dvorak et al., 2005, p. 6; Negt, 1969; Zeuner, 2009, p. 268) and through which people should find orientation in a society marked by erosion crises. This meta-competence is composed of the following six social competences: identity competence/competence of self-perception and perception of others, technical competence, ecological competence, historical competence, competence of social justice and economic competence.

All six social competences are related to each other and enable the subjects to think in contexts, as well as allowing for emancipation and 'Mündigkeit' (empowerment) (Zeuner, 2009, p. 275). Identity competence and historical competence are particularly 
important for the current article and for the question of crises and visions of the occupational future of long-term unemployed people. Accordingly, I briefly discuss these two competences in more detail (for more in-depth information on the other four social competences, cf. Negt, 2010; Rasmussen, 2021; Zeuner, 2013).

Negt understands 'identity competence' as an enlightened way of dealing with threatened and broken identities in a changing society, in which the familiar structures that provide orientation in the family, the working environment and society have eroded (Negt, 2010, p. 223). Therefore, it is about understanding the fundamental social changes and how individuals can deal with them. Identity competence is also understood as the competence of self-perception and perception of others, which is needed to redevelop eroded individual and societal values. This shows a close relationship with the historical competence, which is also one of the six social competences and which consists of the ability to remember and the ability to create a utopia. Historical competence aims to create connections between the past, the present and the future and to develop awareness of one's own needs and interests, one's own social situation and the social situation of others (Dvorak et al., 2005). The past, present and future are closely linked but not always present in people's consciousness, or they are destroyed by crises such as unemployment and the associated experiences of individual helplessness and inability to act (Dvorak et al., 2005, p. 23).

From the perspective of milieu theory, it is assumed that the 'underprivileged' do not have the competence to anticipate the future (Vester et al., 2001); they probably also have good reasons for not trying to explore a future that might be uncertain because insecure jobs, precarious employment relationships, the constant risks of unemployment or long durations of unemployment lead to a feeling of helplessness instead of motivation. Peter Faulstich (2003) compares long-term unemployment with a wall, describing it as a barrier limiting all the possibilities of visions of the future and how to plan the future behind this wall. The subjective reasons for or against anticipating one's occupational future can be examined with the help of subject science learning theory (Holzkamp, 1995).

\section{The subject science perspective: Learning between problem of action, anticipation and phenomenal biography}

The past, present and future are also connected in the subject science theory of learning (Holzkamp, 1995). Similar to utopias, the starting point of learning, which is a specific form of action, is an existing 'problem of action' (Holzkamp, 1995, p. 187). This 'problem of action' is perceived as such by the subject when the possibilities of being able to dispose of one's own life circumstances or participation in social processes is limited. For Anke Grotlüschen (2015), the expansion of possibilities to act is not a perfection of the self or an increase in efficiency in the neoliberal sense; on the contrary, the improvement or expansion of living conditions follow a materialistic logic. It is about the distribution of conflicts in society: 'Therefore, extended influence on personal circumstances is always a question of poverty and wealth, of secure jobs and influence and of political codetermination' (Grotlüschen, 2015, p. 6).

Hence, if subjects encounter a so-called problem of action, they decide, according to Holzkamp, whether to enter a learning loop/learning activity or not. From the standpoint of the subject, this decision can be accompanied by the goal of increasing one's influence to act in the respective given social conditions and, consequently, also by the expansion of one's quality of life. In this sense, the decision for action and learning is justified 'expansively' (Holzkamp, 1995, p. 190; Schraube \& Osterkamp, 2013, p. 123f.). On the 
contrary, if the course of a learning loop is subjectively justified with the aim of averting a threat to the possibilities to act, the learning activity is grounded 'defensively' (Holzkamp, 1995; Schraube \& Osterkamp, 2013, p. 123ff.). For example, when the contents of a promoted continuing vocational training are determined only by the interests of the employment agency and could cause money cuts in case of non-participation. Regardless of the subjective justification, the subject must anticipate whether and why the action or learning is worthwhile before making a decision. At the same time, the phenomenal biography represents an important criterion with which the subject reflects on its previous problems and goals and on which possibilities and obstacles were experienced as beneficial or inhibiting (Holzkamp, 1995, p. 336).

Both, the utopia-theoretical approach and subject science theory, argue that crises imply the potential to initiate learning processes and that visions of the future, especially utopias, can build a space of possibilities. This is not primarily a question of realising a concrete action, but of having, first of all, a vision of future possibilities, created by thoughts. These thoughts can contribute to perceive oneself as being able to act and to find a way out of powerlessness and current crises.

What visions of the occupational future long-term unemployed people have and to what extent long-term unemployment is perceived as a crisis will be explained below using the central results of the study.

\section{Visions of the occupational future of the long-term unemployed - analysed by a biographical and subject science perspective}

Both theoretical perspectives - concepts of utopia in critical theory and subject science theory - emphasise the connection between a present crisis or present problem of action, an utopia or anticipation of the future and reminders or experiences from the past. With this in mind, the study presented here draws on a biographical research method that allows the connection between the past, present and future to be examined.

The investigation of the visions of the occupational future of long-term unemployed people was carried out in an open biographical-narrative interview process (Schütze, 1983). Openness is a fundamental prerequisite for this interpretive research paradigm so as to give the interviewee space to tell whatever they consider to be relevant (Felden, 2012). From a subject science perspective as well, openness is vital to ascertain and analyse the standpoint of the subject towards social conditions and the assessment of one's options for action. Long-term unemployed people often have to justify their situation, they are repeatedly stigmatised as lazy and unmotivated and are also constantly forced by the labour market administration to participate in courses of further education or vocational education without being asked for own occupational interests and desires and are, thus, often kept without any possibility of codetermination. (Butterwegge, 2015; Ludwig-Mayerhofer et al., 2009; Teiwes-Kügler, 2017). Therefore, to avoid suggestive questions and questions that could create pressure, the interviews began by asking the interviewees to tell their life stories.

\section{Sample}

Nine long-term unemployed people aged between 19 and 58 were interviewed. At the time of the survey (2013-2014), they had not worked for between 2 and 15 years. It is important to note that six of the interviewees had completed a vocational training 
(housekeeping (2x), cooking, bricklaying, dental assistant and road construction). Compared with the long-term unemployed in the general population, this is above average (Spermann, 2014). There were five female and four male interviewees. Three of the women were single parents, one woman's children were already grown up and had moved out.

With regard to the interpretation of the results, it is important to consider the possibilities for 'social inclusion' provided for the people interviewed. Social inclusion in this sense means that all of them had access to a social centre, offering education, gatherings and counselling for people in unemployment, or participated in courses for adult basic education or in debt counselling offers. In the sampling process, it was not possible to establish contact with long-term unemployed interviewees via the employment service, because the service could not or was not allowed to forward me to the respective employment service contact person. Therefore, snowball sampling was used by means of staff working in the educational and social institutions and offers mentioned above, which provided me with the necessary access to these places and to persons in long-term unemployment.

The names of the interview partners were anonymised through the use of pseudonyms. As the pseudonym, the first career aspiration or the first profession learned was chosen (e.g. Ms Dental Assistant). All sequences of the interviews presented in the following chapter are translated from German to English by me.

\section{Three types of visions of the occupational future}

The interviews were examined using a narrative analysis to find out about the interviewees' current and former visions of their future and to reconstruct the process structures of their life courses. Fritz Schütze (1983, p. 284) assumes that four process structures can be found in all life courses: biographical scheme of action, institutional process pattern, curves of suffering and processes of inner change; they differ in terms of the possibilities for action perceived in different phases of life. Similar to these process structures, in the empirical data set, three types of visions of the occupational future were identified as findings of the study: individually self-determined visions, institutionaladapted visions and seemingly no visions of the occupational future (in detail: Bonna, 2018, p. 209ff.). It is important to note that these types are not referring to the type of a person, but identify the type of visions of the occupational future. In general, all three types can evolve as dominant in different life stages of a person's biography. Therefore, changing processes of the vision types in the life course are likely to happen.

The individually self-determined type of visions of the occupational future is characterised by the concrete career aspirations that often arise in childhood or adolescence. These are frequently attributed to having had contact with an object of interest (e.g. cooking, baking, sewing). In addition, these visions can be associated with specific expectations of work, for example, that work should be meaningful or challenging. Not only are visions of the occupational future mentioned in the dataset, but also concrete plans are elaborated with regard to how these ideas and visions can be realised. For this, the subject reflects earlier experiences, as well as interests and competences. Life phases in which this type of vision of the occupational future is dominant are also associated with a self-perceived ability to act, which can be strengthened by experiences of overcoming obstacles:

I finished secondary school and in the last three years of school I learned to cook. Back then, it was called housekeeping for boys. Then, I switched to baking. I knew how to bake 
because of my grandad [...], and I wanted to be a cook. The family was against it. But the teacher said that because I was the best she'd ever taught (...) and I already had the experience, I should get a proper qualification, and I made an appointment with my parents and made it clear to them that it really makes sense for me to do it. And then the family was all for it again. So I started the cookery apprenticeship. (Mr Cook, 146-153)

The example of Mr Cook is typical of a biographical phase of life in which ideas about the future are individually self-determined. Above all, the experience of convincing his parents of his career aspirations with the help of his teacher led to the realisation of this career aspiration and ability to act. This shows an expansively justified acting and learning (Holzkamp, 1995) and is also relevant for future occupational visions and decisions. This future oriented type is often found when the subject is in a phase of life in which the process structure (Schütze, 1983) of the biographical action scheme is dominant, which goes hand in hand with one's perceived ability to act.

The institutional-adapted type of vision of the occupational future, the second type, is similar to the individually self-determined one. The difference, however, is that obstacles to the realisation of career aspirations could not be overcome. Obstacles are created by external conditions, such as not being able to find an apprenticeship position in the desired occupation:

Professionally, yes, I tried to become a baker. I liked baking a lot at home and tried to become a baker. But I didn't get a job and they advised me against it, so just to do something I chose an alternative profession ((laughs)) - bricklayer ((laughs)). (Mr Baker-Carpenter, 31-36)

In all cases in which this type of vision of the occupational future occurs in the life course, there are external circumstances and conditions - termed as 'discrepancy experiences' by Holzkamp (1995, p. 212ff.) - that are perceived and that generate an adjustment of occupational visions. This adjustment is based on a capitalistic and neoliberal norm orientation (social expectations to complete vocational training or to be gainfully employed), but also on an existential threat (being unable to support one's family). It is precisely this decisive criterion, the subjective reason for action, that can be used to determine whether we are dealing with individually self-determined or institutionaladapted ideas about one's occupational future. If the justifications are of an expansive nature and accompanied with the goal of increasing one's quality of life and one's (occupational) interests, this suggests an individually self-determined vision of the future. Defensively justified action, on the other hand, points to institutional-adapted visions of the occupational future to avert the threat to the possibilities of action and the quality of life.

The third type of vision of the occupational future - seemingly no visions of the occupational future - is distinct from the first two ones. Despite the interviewer's enquiries, there is no or hardly any access to the future. At first glance, the occupational future does not seem to have any subjective relevance here. A dominant feature of this type is the perception of not being able to influence one's own future. This goes hand in hand with the perceived lack of possibilities for action. Rather, action is perceived as being determined by external influences and conditions. This is typical for Schütze's process structure curve of suffering and follows the principle of being governed by external conditions. These external conditions appear as unexpected and unpredictable, so the future is equated with fate and does not appear to be organisable in a selfdetermined way (Schütze, 1983). In addition, external conditions such as the demands of the labour market administration as well as experiences of illnesses or of failure generate 
fear of the future and self-doubt. The example of Mr Roadbuilder, who throughout the interview, when talking about the future at all, repeatedly emphasised that he was not capable of planning and shaping his future because he had not learned to do so, shows that, nevertheless, interests do exist:

But working on engines and complicated things like that, that's something I find quite interesting, actually. Um, maybe that would be the point where I would say, yes, I could see myself doing that again. But I've never taken an engine apart or anything, let alone fiddled with it. Uh, I've never had anything to do with that. [...] So, what goes on in an engine, how it works, [...] how the power is generated, how a car is moved, by the engine. That's (...), I'm sure (I'm a bit dumber), but uh, I find it quite interesting, all these little parts, which are then put together, uh, what comes out of it. (Mr Roadbuilder, 447-460)

Mr Roadbuilder only talks about these interests at the end of the interview when asked by the interviewer. In his life, however, he does not pursue his interest in car engines because he does not have what he considers to be the necessary intelligence or general education. In another sequence of the interview, he attributes this to the fact that he attended a school for children with special needs.

Thus, this is an example of the type of having seemingly no ideas about one's occupational future. According to Holzkamp (1987), this future oriented type can also be interpreted as a subjectively and biographically based resistance to develop or identify visions of the occupational future, due to repeated experiences of failure regarding maintaining and expanding one's quality of life and the ability to act within the existing social conditions.

Future types cannot be assigned to cases in the sense of a stable, rigid pattern, but they change according to the dominant process structure, which, as Schütze (1983) has pointed out, transforms over the course of one's life. Future types are, just like the process structures of the life course, changeable and bound to the respective current life situation and the associated perceptions of self-determination and possibilities for action. The less a person perceives self-determined possibilities for action, the more likely it is that the future has no relevance in the respective situation, because the experiences of failure and of being governed by external conditions have occurred and occur repeatedly.

\section{Crisis-laden conditions of long-term unemployment and utopian potential}

In addition to the three types of visions of the occupational future, the biographical data material can be used to reconstruct what exactly causes long-term unemployment to become a crisis. This is exemplified in the article by two crisis-laden conditions or rather circumstances: the search for a job that makes people feel happy and the lack of social recognition.

\section{The search for a job that promises happiness}

In their (life) stories, almost all of the interviewees talk about their earliest career aspirations. However, only one person succeeded in realising these aspirations. Four people completed a training in a different profession. Especially the story of Mr BakerCarpenter illustrates how years of searching for a job in one's desired occupation can turn into an individual crisis: 
I somehow never really found a job where I was really (...) happy and where I worked for a long time or would have wanted to ((deep breath)). I did it because you have to do something, but I never actually wanted the work ((laughs)). (Mr Baker-Carpenter, 55-58)

Mr Baker-Carpenter has been interested in baking and crafts since childhood. He was not able to complete training in either profession. Occupational adjustment processes already began with the alternative training he completed as a bricklayer and continued throughout his employment history. In the process, he frequently experienced physical and psychological health problems. To this day, Mr Baker-Carpenter holds on to his occupational aspirations (carpenter), but at the same time he perceives himself as incapable of acting:

Um (7 s), for one thing I don't know what else I can do professionally somehow ( $2 \mathrm{~s})$. Where or what I can do, who with or where, whatever, what I can do, I don't know (2 s). I'll have to see. ( $3 \mathrm{~s})$ And uh (6 s), I've also got into the habit of planning only up to certain points, what happens after that, I wait and see. What I've learned or had to learn from being unemployed, lengthy planning ( $2 \mathrm{~s})$, is just a high risk ( $2 \mathrm{~s})$. Either financially or what the job centre would or wouldn't have from me ((laughs)), $(2 \mathrm{~s})$ is always one of those things. (Mr Baker-Carpenter, 335-342)

Thus, adapting to a performance-oriented labour market society while holding on to subjective interests in life and work may lead to an individual crisis (suffering curve), which is likely to manifest in the form of illnesses, among other things. What is particularly critical here (for the subjective perceived ability to act and for creating visions of the occupational future), is that the perceived failure is subjectivised. Although $\mathrm{Mr}$ Baker-Carpenter attributes his resignation regarding planning his future to the repressive conditions and demands of the labour market administration, he looks for alternative ways to maintain his quality of life and ability to act within the existing conditions to a certain extent and, yet, reproduces them at the same time. Holzkamp refers to this as 'restrictive agency' (Holzkamp, 1985, p. 354) as Mr Baker-Carpenter tries to simultaneously adapt to the performance-oriented expectations of a capitalist labour market society and to those of the labour market administration. In his narrative, he tentatively expresses criticism of the labour market administration, but criticism of social conditions is not voiced, nor are alternative concepts developed.

Both interview quotes show how much Mr Baker-Carpenter has tried to adapt to a performance-oriented (labour) society and how, over the years, he has increasingly lost his orientation and his subjectively perceived ability to act, thus, also his ability to plan his own occupational future.

At the time of the interview, Mr Baker-Carpenter can be seen as being in a progression curve of suffering (Schütze, 1985). Probably, the progression curve is dominant precisely because he is clinging on to his occupational ideas and desires (searching for a job that makes him feeling happy). Despite trying to adapt the ideas and desires under the terms of participation in gainful employment and, thus, in the labour market society, he has failed. For this reason, he has lost hope, he no longer actively follows this career aspiration and has stopped planning his occupational future in the longer term and pursuing it in a self-determined manner. He justifies this with his dependence on the labour market administration and the associated lack of opportunities for codetermination, as well as financial restrictions. In addition, he is no longer able to pursue any activity because of physical impairments attributed to being severely overweight and having back problems. He is officially registered as a person with impairment/disability. At the time of the interview, he was hoping that his application for a reduced earning capacity pension would be accepted so that he could be his 'own man' 
and shape his life according to his ideas and health and pursue his craft and artistic interests in his private leisure time. He finds opportunities for this both at home and at the local social centre, offering education, gatherings and counselling for the unemployed and in general for the people living in the neighbourhood, which he visits regularly and where he takes part in various group activities (e.g. samba course, weekly breakfast).

\section{Lack of social recognition}

Sometimes, neither the occupation (job) itself nor the aim of pursuing gainful employment is highly relevant to the unemployed people interviewed. The crisis here is that care work, for example, is not perceived as valued and recognised. The stigmatisation of being lazy and living at the expense of society, which often goes hand in hand with long-term unemployment, also leads to a crisis-like experience.

For the interviewee, Ms German Army, the lack of social recognition is negatively encouraged by her former housing situation in a high-rise building in a so-called disadvantaged neighbourhood, which, in turn, leads to stigmatisation:

Yes, I can say that, living in such a high-rise complex [...] and having lived with hundreds of people in ONE house, I lived there for 28 years, and you were socially labelled, you were labelled as the LOWEST. Even the one police operation, a young policeman in a house where I lived here, wherever in A-town talked to us in SUCH a shitty way, that's probably the lowest of the low, the people who live here. So, uh and I don't have that anymore, that feeling of being labelled LOWEST. It's just a MUCH more liberated feeling where I live now, that it's finally come true, that I got out of THERE. (Ms German Army, 652-663)

In the narrative of Ms German Army, there is an initial career aspiration that is not realised, yet, the many years of adjustment by taking on any kind of job and her current unemployment are not portrayed by her as problematic or even crisis-like. On the contrary, what has led to feeling stigmatised as worthless since years, even decades of, is her social status and that she, as a single mother of two children, has not found a way out. Her biography also includes multiple illnesses and impairments, which, from her point of view, have severely limited the possibilities of finding a job with which she could have chosen a different living environment and would have attained financial security for herself and her children. In contrast to Mr Baker-Carpenter, Ms German Army shows a much stronger everyday awareness of social structures:

I am also very socially and interculturally minded, so that I can do something to ensure that we don't just watch poverty increase, but that we actually have to stick together so that we don't pull ourselves down completely. Politically, we are being dragged down as we NEVER have been before. [...] Poverty has never been as high as it is now in Germany. I also think about this. But we have to do something in the COMMUNITY so that we don't let ourselves get pushed around here. (Ms German Army, 95-105)

Ms German Army also talks about demonstrations she took part in, against unemployment and against discrimination of women in the workplace. This elicits a strong collective-oriented critique of the social conditions. However, in the dataset, no social utopias have emerged from this critique, or, perhaps, have not been told. Approaches to a critical examination of individual but also collective interests and social conditions are, yet, recognisable in her case. 


\section{Conclusions for learning and utopian thinking in the crisis of long-term unemployment}

The biographical data material does not reveal any statements on social utopias in the sense of critical theory because it shows hardly any explicit criticism of current social conditions that could be a starting point for the development of utopias in the sense of alternative concepts to existing social conditions. However, multiple 'problems of action' (Holzkamp, 1995) are presented, stated as a subjectively perceived limited quality of life and a limited influence to social conditions - in other words, a lack of the ability to act. This limited ability to act is partly attributed to external conditions; yet, unsuccessful adaptive actions are often subjectivised by the interviewees, which means that they declare themselves as responsible for their failures. Considering this, also the interview situation needs to be taken into account. The interviews were conducted by me as a researcher and an academic in employment. This might have provoked the situation that the interviewees were reluctant to express (at least partly) the real amount of criticism towards their personal situation and / or the social conditions of modern society. More frequently, there were sequences of justifying their unemployment situation and how it came to this point, which rather illuminates the perceptions of stigmatisation and failure.

However, the data clearly reveals that, even if long-term unemployed, people do have ideas, interests and wishes about their occupational future. They try to maintain their interests, competences and professional identity through other forms of work (e.g., in the domestic family or voluntary sector) to protect and maintain their own possibilities for action under the respective conditions. This happens in different ways, for example, by dealing with one's own rights and duties as an unemployed person or by following one's own interests in private spaces.

Negt describes unemployment as 'an act of violence that attacks the physical and psychological integrity of those affected' (Negt, 1984, p. 8; translated by the author). Often, it is not the lack of a job or the exclusion from the labour market alone that causes the crisis. Rather, it is the many problems of action and mechanisms of exclusion, the lack of social recognition, stigmatisation, crises in the private and family sphere or crises due to illness. Especially, the type 'seemingly no idea of the occupational future' shows in what ways long-term unemployment can lead to a lack of (perceived) ability to act through these mechanisms and problems of action; in consequence, also a subjectively justified resistance ${ }^{2}$ to planning one's future might be initiated. These are predominantly individual crises that manifest themselves in experiences of suffering; but less so crises that are seen as brought about by social conditions. One could suggest that this exemplifies the power of capitalism and neoliberalism, which is reflected in the actions of the subjects. It concerns the social devaluation and incapacitation of (long-term) unemployed people, who are stigmatised by neoliberal society and medial discourses as 'parasites' (Butterwegge, 2015, p. 240ff.) and are, thus, devalued as non-productive for the capitalist-based labour market society and disciplined by labour market policy measures. According to the findings of the data material, the majority of the long-term unemployed seem to have already internalised this without acting reflexively or opposing against it.

This is the point at which Negt's social competences can be linked. Although adult and continuing education can neither solve the structural problem of unemployment (Holzer, 2014, p. 39), nor end the erosion crisis of the labour society, adult education can enable people to develop social competences by means of critical reflection, thereby promoting a more critical approach to social and individual crises. This is not primarily about reintegration into the labour market, but about a critical rethinking and biographical reinterpretation of the connections (Negt) between individual interests and social 
conditions. Thus, it aims at developing social competences that are not superficially oriented towards usability, qualification and employability, but towards enlightenment, 'Mündigkeit' (empowerment) and the strengthening of the subjective and collective identity of (long-term) unemployed people (Negt, 2002; Pongratz, 2010). Within the framework of the European Grundtvig project 'Political Participation through Societal Competences: Curriculum Development for Basic Political Education', a curriculum of all six societal competences has already been developed (e.g., Dvorak et al., 2005). Such critical-reflexive adult education promotes expansive learning processes by opening up spaces for criticism and for utopias, and, consequently, contributes to empower the perceived ability to act. The strong criticism of the labour market administration, lack of codetermination and stigmatisation that has become evident in the interviews clearly emphasises the viewpoint that there certainly is a potential for utopian thinking - even under the conditions of long-term unemployment.

\section{Notes}

${ }^{1}$ In the 1980s, the phenomenon of mass unemployment had been widely spread in many European countries and had been a key driver for social science studies on social exclusion (Castel, 2000; Kronauer, 2007).

2 There exist a large body of knowledge on this kind of resistance, examined extensively by Daniela Holzer (2017) with regard to continuing education.

\section{References}

Benedetti, S. (2015). Freiwilliges Engagement. Ein bildungsbiografischer Erfahrungsraum. Zeitschrift für Weiterbildungsforschung, Report, 38(1), 53-69.

Bolder, A., Bremer, H., \& Epping, R. (2017). Bildung für Arbeit unter neuer Steuerung. Springer VS.

Bonna, F. (2017). Berufliche Zukunftsvorstellungen Langzeitarbeitsloser aus biographischer Perspektive. In O. Dörner, C. Iller, H. Pätzold, J. Franz, \& B. Schmidt-Hertha (Eds.), Biografie - Lebenslauf Generation. Perspektiven der Erwachsenenbildung (pp. 253-264) Barbara Budrich.

Bonna, F. (2018). Berufliche Zukunftsvorstellungen Langzeitarbeitsloser. Eine biographieanalytische Untersuchung. wbv Verlag.

Brödel, R. (2018). Weiterbildung mit Arbeitslosen. In R. Tippelt, \& A. von Hippel (Eds.), Handbuch Erwachsenenbildung/Weiterbildung (pp. 1363-1382). Springer.

Bundesagentur für Arbeit, Statistik/Arbeitsmarktberichterstattung. (2019). Arbeitsmarktsituation von langzeitarbeitslosen Menschen. https://statistik.arbeitsagentur.de/DE/StatischerContent/Statistiken/Themen-im-Fokus/Langzeitarbeitslosigkeit/generischePublikationen/Langzeitarbeitslosigkeit.pdf?_blob=publicationFile\&v $=4$.

Butterwegge, C. (2015). Hartz IV und die Folgen. Auf dem Weg in eine andere Republik? Beltz Juventa.

Castel, R. (2000). The Roads to Disaffiliation: Insecure Work and Vulnerable Relationships. International Journal of Urban and Regional Research, 24(3), 519-535.

Dehnbostel, P. (2007). Lernen im Prozess der Arbeit. Waxmann.

Düx, W., Prein, G., Sass, E., \& Tully, C. J. (2009). Kompetenzerwerb im freiwilligen Engagement. Eine empirische Studie zum informellen Lernen im Jugendalter. VS Verlag für Sozialwissenschaften.

Dvorak, J., Zeuner, C., \& Franke, A. (2005). Politische Partizipation durch gesellschaftliche Kompetenz: Curriculumsentwicklung für die politische Grundbildung. Historische Kompetenz. Universität Flensburg. http://www.hsu-hh.de/zeuner/index_o3RBEFQKMp7s3elZ.html.

Epping, R., Klein, R., \& Reutter, G. (2001). Langzeitarbeitslosigkeit und berufliche Weiterbildung. Didaktisch-methodische Orientierungen. Bertelsmann.

Eurostat (2021). Unemployment rate in member states of the European Union in January 2021. https://www.statista.com/statistics/268830/unemployment-rate-in-eu-countries/.

Faulstich, P. (1990). Zukunft. In P. Faulstich (Ed.), LernKultur 2006. Erwachsenenbildung und Weiterbildung in der Zukunftsgesellschaft (pp. 14-43). Lexika. 
Faulstich, P. (2003). Zukunftsperspektiven aus der Weiterbildungsmisere. Bundesverband der beruflichen Träger beruflicher Bildung.

Felden, H. von (2012). Narratives Interview. In B. Schäffer \& O. Dörner (Eds.), Handbuch Qualitative Erwachsenen- und Weiterbildungsforschung (pp. 334-346). Barbara Budrich.

Grotlüschen, A. (2015). Neo subject-scientific learning theory. A reinterpretation. https://www.researchgate.net/publication/320756370_Neo_subjectscientific_learning theory_A_Reinterpretation.

Hermeling, S. (2017). 'Dann bist $\bar{d} u$ wieder ein Jahr älter und hast immer noch nichts erreicht.' Die Förderung beruflicher Weiterbildung im Hartz-IV-System. In A. Bolder, H. Bremer, \& R. Epping (Eds.), Bildung für Arbeit unter neuer Steuerung (pp. 341-364). Springer VS.

Holzer, D. (2014). Weiterbildung ist die falsche Antwort auf falsche Fragen. In I. Erler (Ed.), Wenn Weiterbildung die Antwort ist, was war die Frage? (pp. 37-48). Studien Verlag. https://schulheft.at/wp-content/uploads/2018/02/schulheft-156.pdf.

Holzer, D. (2017). Weiterbildungswiderstand. Eine kritische Theorie der Verweigerung. Bielefeld:transcript

Holzkamp, K. (1985). Grundlegung der Psychologie. Campus-Verlag.

Holzkamp, K. (1987). Lernen und Lernwiderstand. Skizzen zu einer subjektwissenschaftlichen Lerntheorie. Forum Kritische Psychologie (20), 5-35.

Holzkamp, K. (1995). Lernen. Subjektwissenschaftliche Grundlegung. Campus-Verl.

Horkheimer, M. (1930). Anfänge der bürgerlichen Geschichtsphilosophie. Kohlhammer.

Horkheimer, M. (1986). Die Utopie. In A. Neusüss (Ed.), Utopie. Begriff und Phänomen des Utopischen (pp. 178-192). Campus-Verl.

Jahoda, M., Lazarsfeld, P., \& Zeisel, H. (1986). Die Arbeitslosen von Marienthal. Ein soziographischer Versuch. Suhrkamp.

Kronauer, M. (2007). Inklusion ... Exklusion: ein Klärungsversuch. http://www.diebonn.de/doks/kronauer0701.pdf.

Ludwig-Mayerhofer, W., Behrend, O., \& Sondermann, A. (2008). Disziplinieren und Motivieren: Zur Praxis der neuen Arbeitsmarktpolitik. In A. Evers, \& R. G. Heinze (Eds.), Sozialpolitik. Ökonomisierung und Entgrenzung. VS Verlag für Sozialwissenschaften.

Ludwig-Mayerhofer, W., Behrend, O., \& Sondermann, A. (2009). Auf der Suche nach der verlorenen Arbeit. Arbeitslose und Arbeitsvermittler im neuen Arbeitsmarktregime. UVK-Verlag.

Meier, A. (1998). Weiterbildungsnutzen. Über beabsichtigte und nicht beabsichtigte Effekte von Fortbildung und Umschulung. Trafo-Verlag. http://www.worldcat.org/oclc/75828586.

Negt, O. (1969). Soziologische Phantasie und exemplarisches Lernen. Zur Theorie der Arbeiterbildung. Europäische Verlagsanstalt.

Negt, O. (1984). Lebendige Arbeit, enteignete Zeit. Politische und kulturelle Dimensionen des Kampfes um die Arbeitszeit. Campus.

Negt, O. (1993). Wir brauchen eine zweite, gesamtdeutsche Bildungsreform. http://library.fes.de/gmh/main/pdf-files/gmh/1993/1993-11-a-657.pdf.

Negt, O. (2002). Arbeit und menschliche Würde. Steidl Verlag.

Negt, O. (2010). Der politische Mensch. Demokratie als Lebensform. Steidl Verlag.

Negt, O. (2012). Arbeit als Lebensbedürfnis. Netzwerk Gesellschaftsethik e.V. http://www.denk-dochmal.de/sites/denk-doch-mal.de/files/Negt.pdf.

Peters, S. (1991). Arbeitslose und ihr Selbstbild in einer betrieblichen Umschulung. Lern- und Leistungsfähigkeit in Bilanzierung und Antizipation in einer Metallfacharbeiterausbildung. Deutscher Studien Verlag.

Pongratz, L. A. (2010). Kritische Erwachsenenbildung. Analysen und Anstöße. VS Verlag.

Rasmussen, P. (2021). Public reason, adult education and social imagination. European Journal for Research on the Education and Learning of Adults, 12(1), 15-29. http://doi.org/10.3384/rela.2000$7426.0 j \mathrm{~s} 3465$.

Reutter, G. (2009). Qualifikationen vermitteln - Schlüsselqualifikationen fördern - Kompetenzen erfassen und messen? Eine Zeitreise. In A. Bolder, \& R. Dobischat (Eds.), Eigen-Sinn und Widerstand. Kritische Beiträge zum Kompetenzentwicklungsdiskurs (pp. 36-53). VS Verlag für Sozialwissenschaften.

Salling Olesen, H. (2013). Beyond the current political economy of competence development. European Journal for Research on the Education and Learning of Adults, 4(2), 153-175. http://www.rela.ep.liu.se/issues/10.3384_rela.2000-7426.201342/rela9013/rela9013.pdf. 
Schraube, E., \& Osterkamp, U. (2013). Psychology from the standpoint of the subject. selected writings of Klaus Holzkamp. Palgrave Macmillan.

Schütze, F. (1983). Biographieforschung und narratives Interview. http://www.ssoar.info/ssoar/bitstream/handle/document/5314/ssoar-np-1983-3-schutzebiographieforschung_und_narratives_interview.pdf?sequence $=1$.

Semmer, N. K., \& Meier, L. L. (2014). Bedeutung und Wirkung von Arbeit. In H. Schuler, \& K. Moser (Eds.), Lehrbuch Organisationspsychologie (pp. 559-604). Hogrefe Verlag.

Spermann, A. (2014). Zehn Jahre Hartz IV - Was hilft Langzeitarbeitslosen wirklich? IZA Standpunkte, 76. http://ftp.iza.org/sp76.pdf.

Teiwes-Kügler, C. (2017). Vermittlungs- und Bildungspraxis der Arbeitsverwaltung - Widersprüche zu Habitus und Berufsbiographie. In A. Bolder, H. Bremer, \& R. Epping (Eds.), Bildung für Arbeit unter neuer Steuerung (pp. 365-388). Springer VS.

Vester, M., Oertzen, P., von, Geiling, H., Hermann, T., \& Müller, D. (2001). Soziale Milieus im gesellschaftlichen Strukturwandel. Zwischen Integration und Ausgrenzung. Suhrkamp.

Zeuner, C. (2009). Zur Bedeutung gesellschaftlicher Kompetenzen im Sinne eines kritischen bildungstheoretischen Ansatzes. In A. Bolder, \& R. Dobischat (Eds.), Eigen-Sinn und Widerstand. Kritische Beiträge zum Kompetenzentwicklungsdiskurs (pp. 260-281).VS Verlag für Sozialwissenschaften.

Zeuner, C. (2013). From workers education to societal competencies: Approaches to a critical, emancipatory education for democracy. European Journal for Research on the Education and Learning of Adults, 4(2), 139-152. 10.3384/rela.2000-7426.rela9011. 